\title{
Does the oscillation of the water volume of the reservoir influence in the same way in fish diet?
}

\author{
A oscilação do volume de água do reservatório influencia da mesma forma na \\ dieta de peixes?
}

Jean Carlos Dantas de Oliveira ${ }^{1 *}$, Jônnata Fernandes de Oliveira²,

Luzia Geize Fernandes Rebouças ${ }^{1}$, José Luís Costa Novaes ${ }^{1}$ and Danielle Peretti ${ }^{3}$

${ }^{1}$ Departamento de Biociências, Universidade Federal Rural do Semi-Árido - UFERSA, BR 110, Km 47, Bairro Costa e Silva, CEP 59625-900, Mossoró, RN, Brasil

${ }^{2}$ Instituto Federal do Maranhão - IFMA, Campus Avançado Carolina, Praça Santo Antônio, 93, Centro, CEP 65980-000, Carolina, MA, Brasil

${ }^{3}$ Departamento de Ciências Biológicas, Universidade do Estado do Rio Grande do Norte - UERN, Av. Prof. Antônio Campos, s/n, Bairro Costa e Silva, CEP 59625-620, Mossoró, RN, Brasil *e-mail: jeancarlosdo@hotmail.com

Cite as: Oliveira, J.C.D. et al. Does the oscillation of the water volume of the reservoir influence in the same way in fish diet? Acta Limnologica Brasiliensia, 2018, vol. 30, e104.

Abstract: Aim: To evaluate the fish feeding and to establish the preferential and secondary items of their diets, to determine the trophic guilds and the possible trophic structure variations in function of the water volume in Umari reservoir, Rio Grande do Norte, Brazilian semiarid. Methods: The fish were captured quarterly between February and November of 2013, with gill nets with different meshes, being the apparatuses exposed at 5:00 p.m., with removal at 5:00 a.m. The food items were identified using stereoscopic and optical microscopes and evaluated through the Feeding Index (IAi), being the results of this procedure used in food similarity analysis. The volume of the items was orderly in NMDS and the time differences were tested in PERMANOVA. Results: A total of 740 individuals belonging to 14 species were sampled, being analyzed a total of 258 stomachs and 8 intestines of 11 species. From the IAi values used in the trophic similarity analysis, the species were classified into five trophic guilds: detritivorous, insectivorous, malacophagous, carcinophagous and piscivorous. Conclusion: The oscillation in the water volume of the reservoir did not influence the diet of the guild detritivorous, which shows that the variations in the volume of water of the reservoir do not influence in the same way the diet of the local ichthyofauna.

Keywords: feeding; trophic guilds; ichthyofauna; semiarid.

Resumo: Objetivo: Avaliar a alimentação de peixes e estabelecer os itens preferenciais e secundários de suas dietas, a fim de determinar as guildas tróficas e as possíveis variaçôes da estrutura trófica em função do volume de água no reservatório de Umari, Rio Grande do Norte, semiárido brasileiro. Métodos: Os peixes foram capturados trimestralmente entre fevereiro e novembro de 2013, com redes de espera de diferentes malhas, sendo os aparatos expostos às $17 \mathrm{~h}$, com despesca às $5 \mathrm{~h}$. Os itens alimentares foram identificados, com auxílio de microscópios estereoscópico e óptico e avaliados através do Índice Alimentar (IAi), sendo os resultados desse procedimento utilizados em análise de similaridade alimentar. O volume dos itens foi ordenado em NMDS e as diferenças temporais testadas em PERMANOVA. Resultados: Foram coletados 740 indivíduos, pertencentes a 14 espécies, sendo analisado um total de 258 estômagos e oito intestinos de 11 espécies. A partir dos valores do 
IAi utilizados na análise de similaridade trófica, as espécies foram classificadas em cinco guildas tróficas: detritívora, insetívora, malacófaga, carcinófaga e piscívora. Conclusão: A oscilação no volume de água do reservatório não influenciou a dieta da guilda detritívora, o que demonstra que as variaçóes no volume de água do reservatório náo influenciam da mesma maneira a dieta da ictiofauna local.

Palavras-chave: alimentação; guildas tróficas; ictiofauna; semiárido.

\section{Introduction}

The construction of reservoirs in Brazil is intense, especially in the semiarid regions, promoting an increasing interest in fish feeding studies, mainly on diet and feeding habits, allowing identifying trophic guilds, habitat use and the trophic relations of the ichthyofauna in dammed ecosystems. This knowledge contributes to the development of sustainable management strategies of the reservoirs where the fish have adapted to the modified environment. Changes in fish diet may occur according to the abundance or scarcity of food resources throughout the year (Silva et al., 2012b). Studies have indicated that disturbances resulting from damming are fundamental elements in the reorganization of local fish assemblages (Agostinho et al., 2008), being the food availability one of the main factors limiting the initial fish colonization in the new environment (Merona \& Vigouroux, 2012).

The studies on natural feeding of fish and the establishment of the trophic structure have been highlighted by providing information on the functioning of the ecosystem in which the species are inserted (Oliveira et al., 2016a). Study the diet and fish food interaction provides ecological information, such as the mechanisms that allow the coexistence and exploitation of resources by several species (Goulding, 1980), as well as to understand the behavior of species in the face of changes in environmental conditions and food availability (Silva et al., 2012b). Thus, studies on the diet of fish are of great importance because they are directly related to obtaining energy and help to understand the activities involved in the development, growth, reproduction and maintenance processes of the organism (Gandini et al., 2014; Bonato et al., 2012; Ribeiro et al., 2014).

The variation of the water level at which the reservoirs are submitted annually is another relevant aspect related to the trophic structure, which can result in changes in the fish diet, once that the hydrological routes affect the food resources availability (Santos et al., 2014). The seasonality and spatiality of the reservoirs also exert influence on the fish assemblage trophic structure (Agostinho et al.,
2007). During the rainy season occurs flooding of land areas, expanding the aquatic environment and originating new habitats for feeding, at which fish often transit, strongly influencing the food type consumed (Moraes et al., 2013), the opposite occurs during the dry, with the reduction of the water volume. Besides, the stored water in reservoirs suffers constant changes in their volume, mainly by the evaporation process, as in the semiarid regions where it is estimated that about $40 \%$ of the accumulated water is lost by evaporation (Meireles et al., 2007).

Considering the effect of the water volume oscillations in reservoirs and how it interacts with fish feeding, are these changes in the water level influence, in the same way, the ichthyofauna diet? This study aimed was to evaluate the feeding of fish species and to establish the preferential items of their diets, to determine the trophic guilds and the possible variations of the trophic structure in function of the water volume in the reservoir of Umari, Rio Grande do Norte, Brazil.

\section{Material and Methods}

\subsection{Study area}

The Senador Jessé Pinto Freire Dam, popularly known as Umari reservoir. It is located at $8 \mathrm{~km}$ on the amount from the office of Upanema city, located in the West Potiguar mesoregion and in the Midwest micro region (Figure 1). The reservoir was concluded in 2002, through the Carmo river dam, which belongs to the Apodi-Mossoró river basin, which represents the largest genuinely Potiguar river basin. The Umari reservoir holds the third largest water reservoir capacity of the state, with approximately $292.813 .650 \mathrm{~m}^{3}$ (SEMARH, 2013).

\subsection{Sample}

The collect occurred quarterly, during the months of February, May, August and November of 2013, with four field days in each. The fishing apparatuses were exposed at 05:00 p.m. along the reservoir and along its margins, at five distinct points (Figure 1), as a way to try to collect as much information as possible, remaining for a period of $12 \mathrm{~h}$, with fish removal at 05:00 a.m. All were 
performed with the same effort, composed of eleven gill nets with the following meshes: 12, 15, 20, 25, $30,35,40,45,50,60$ and $70 \mathrm{~mm}$ (between adjacent nodes), with $15 \mathrm{~m}$ length and height of $2.0 \mathrm{~m}$.

For all the points were made notes, about the characteristics of the environment: type of background (sand, stone, gravel or mud), presence of macrophytes, erosion of the margins, marginal vegetation, quantity of dead wood standing (dead trees after the formation of reservoir) and water transparency (with Secchi disk) (Table 1).

\subsection{Accumulated rainfall data and the accumulated water volume of the reservoir}

The accumulated rainfall data $(\mathrm{mm})$, area and the accumulated water volume of the reservoir (in \%) were obtained from the offices of the
Agricultural Research Company of Rio Grande do Norte (EMPARN, 2016) and the Secretariat of the State of the Environment and Hydric Resources (SEMARH, 2016).

\subsection{Procedures with the sampled specimens}

The captured specimens were packed in plastic bags properly identified with collect points, time and capture apparatus. In the field, the material was screened and identified up to the taxonomic level. Some specimens of the species were sent to the taxonomist of the Federal University of Paraíba (Universidade Federal da Paraíba - UFPB) for confirmation or correction in the identification of the species, where are deposited in the ichthyology collection of the institution (UFPB: 8934-8986). After taxonomic identification, the specimens were
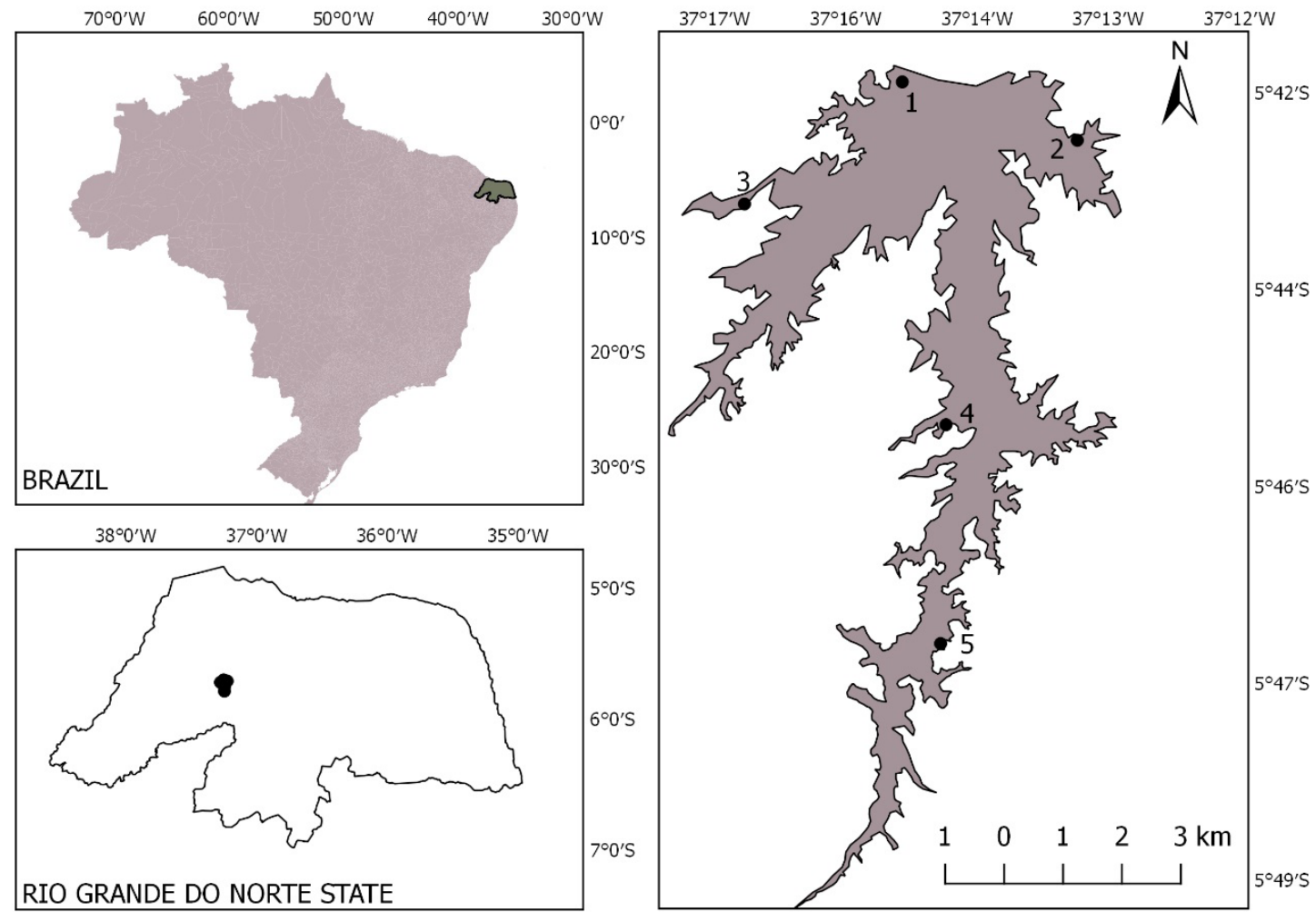

Figure 1. Location of the collection points of fish on the Umari reservoir, the hydrographic basin of the Apodi-Mossoró river, Rio Grande do Norte, Brazil.

Table 1. General characteristics of collection points in the Umari reservoir, Rio Grande do Norte, Brazil.

\begin{tabular}{cccccccc}
\hline Site & A & B & C & D & E & F & G \\
\hline 1 & Sand and gravel & Absent & Absent & Moderate & Grass and shrub & High & $135 \mathrm{~m}$ \\
2 & Sand and gravel & Absent & Absent & Moderate & Grass and shrub & High & $160 \mathrm{~m}$ \\
3 & Sand and stone & Absent & Absent & Narrow & Grass and shrub & High & $116 \mathrm{~m}$ \\
4 & Sand and stone & Present & Absent & Very narrow & Grass and shrub & Moderate & $140 \mathrm{~m}$ \\
5 & Sand and gravel & Absent & Absent & Moderate & Grass and shrub & High & $118 \mathrm{~m}$ \\
\hline
\end{tabular}

$\mathrm{A}=$ type of background; $\mathrm{B}=$ presence of macrophytes; $\mathrm{C}=$ erosion of the margins; $\mathrm{D}=$ marginal vegetation; $\mathrm{E}=$ type of vegetation; $F$ = quantity of dead wood standing; $G$ = water transparency. 
sectioned in the ventral region, being the stomachs and intestines removed (for the Loricariidae family specimens), which were fixed in 10\% formaldehyde and transported to the Laboratory of Ichthyology (Laboratório de Ictiologia - LABIC) of the University of the State of Rio Grande do Norte (Universidade do Estado do Rio Grande do Norte - UERN), for the analysis procedures of the feeding content.

\subsection{Feeding content analysis}

For the analysis were considered species that contained three or more stomachs with food contents. Initially, the food items were identified, using stereoscopic and optical microscopes, at the lowest possible taxonomic level with the aid of specialized literature (McCafferty, 1981; Needham \& Needham, 1982; Merritt \& Cummins, 1996). From the identified items, its volume was obtained, following two procedures, which were applied according to the type and dimension of the food: i) through graduated testers tube whose volume is given by liquid displacement (Hynes, 1950; Hyslop, 1980; Zavala-Camin, 1996); And ii) by the millimeter Petri dish method (Hellawell \& Abel, 1971).

Specimens that had the intestine as an object of study, the analysis was performed from the content present in the anterior portion of the lumen, corresponding to $10 \%$ of the total length (Peretti \& Andrian, 2004), being this suspended in $70 \%$ alcohol and through a pipette, a sample of the solution removal, for making slide and microscopic investigation. From the diet, data have obtained the frequency of occurrence $(\mathrm{Fo})$ and volumetric $(\mathrm{Fv})$ (Hynes, 1950; Hyslop, 1980; Rosecchi \& Nouaze, 1987; Zavala-Camin, 1996). The association of the frequencies gave rise to the calculation of Feeding Index (IAi) (Kawakami \& Vazzoler, 1980), presented in percentage values (Equation 1).

$\mathrm{IAi}=\left[\mathrm{Fo}_{\mathrm{O}} . \mathrm{Fv}_{\mathrm{v}} / \Sigma\left(\mathrm{Fo}_{\mathrm{O}} . \mathrm{Fv}_{\mathrm{v}}\right)\right] \mathrm{x} 100$

wherein: $I A i=$ Feeding Index - Simultaneously expresses the frequency of occurrence and volumetric methods, generating an index that confirms the main food resources of the diet; $F o=$ frequency of occurrence - expresses the number of stomachs that contain a given food item in relation to the total of analyzed stomachs; $F v=$ volumetric frequency expresses the contribution of the volume $(\mathrm{mL})$ of each category in relation to the total of all analyzed contents.
To evaluate the preferential items and determine the feeding habits of the species was used to scale of Rosecchi \& Nouaze (1987). Wherein: IAi $>50 \%$ - preferential item; $25<\mathrm{IAi}<50 \%$ secondary item; IAi $<25 \%$ - accessory item.

\subsection{Statistical analysis}

The IAi values of the species were used to evaluate the food similarity to establish the trophic categories, in a similarity matrix using the Morisita index, and the Unweighted Pair-Group Method using Average (UPGMA). Afterward, the similarity matrix was compared with a cophenetic matrix to evaluate the consistency of the clustering pattern, being that values close to the unit indicate a better representation (Cruz \& Carneiro, 2003).

To verify if variations in the reservoir water volume do influence in the organization of the trophic guilds, the volume values of the food items of each species were used in a similarity matrix, using the Bray-Curtis similarity coefficient. The results of each procedure were used in Non-Metric Multidimensional Scaling (NMDS) to evaluate the use of food resources by the species in the sampling period. To verify variations in the feeding guilds, were carried out the Permutational Multivariate Analysis of Variance (PERMANOVA), using the Bray-Curtis similarity index. NMDS analysis was not carried out for the piscivorous guild because only four stomachs were analyzed. For the data analysis was used the program Paleontological Statistics (PAST) version 2.14 (Hammer et al., 2004).

\section{Results}

During the whole sampling period, the Umari reservoir presented variations in the precipitation ranged between $92.1 \mathrm{~mm}$ (February) and $0 \mathrm{~mm}$ (August), with the highest amounts in February and May. The highest values water volume and area being the recorded for the months of May and August, and the lowest values in the months of February and November of 2013 (Table 2).

A total of 740 individuals were collected, distributed into 3 orders, 9 families and 14 species, but 11 species presented three or more specimens with food content. From this criterion, a total of 258 stomachs and 8 intestines of Hypostomus pusarum were analyzed (Table 3) for which, the analysis was made, similarity calculation and trophic categorization for these individuals.

The analysis of the stomach/intestinal content of the fish assemblage allowed the identification 
of 24 food items (Table 4) grouped into three major food categories: animal, composed of insects that constituted the greatest diversity, represented by the orders: Hymenoptera, Odonata, Coleoptera, Diptera, Ephemeroptera, Hemiptera, Lepidoptera, Orthoptera and Trichoptera. Also, were recorded shrimp, arachnids (scorpion and spider), protozoa, mollusks, microcrustaceans (conchostracan) and fish. For vegetal items, are found plant residues (leaves, branches, seeds, fruits, and bark), Chlorophyceae algae (unidentified) and microalgae (Cyanophyceae and Diatomaceae).

Table 2. Monthly water indexes, Precipitation ( $\mathrm{mm}$ ), Volume $\left(\mathrm{m}^{3}\right)$ and Area $\left(\mathrm{m}^{2}\right)$ of the Umari reservoir, Rio Grande do Norte, Brazil, in the year 2013.

\begin{tabular}{cccc}
\hline Date & Precipitation & Volume $\left(\mathbf{m}^{3}\right)$ & Area $\left(\mathbf{m}^{2}\right)$ \\
\hline $02 / 2013$ & 92.1 & 127.544 .608 & 16.918 .628 \\
$05 / 2013$ & 51.4 & 185.935 .052 & 21.672 .766 \\
$08 / 2013$ & 0 & 175.357 .073 & 20.811 .420 \\
$11 / 2013$ & 6.3 & 152.720 .198 & 18.968 .142 \\
\hline
\end{tabular}

Regarding the item detritus/sediment that differ in their proportion of organic and inorganic material, these were predominantly constituted of detritus, sediment, animal and plant in advanced stages of decomposition.

From the analysis of the food items, distributed by categories in relation to their respective diets, the IAi was calculated, and attributed the preferential and secondary food items of the ichthyofauna, according to Rosecchi \& Nouaze (1987) scale. Most of the species presented one or more dominant resources in the diet, being registered changes in the consumption of the items during the sample period (Table 4).

Based on the values of the Feeding Index (IAi) of the 11 species in the of trophic similarity analysis, the species were classified in five guilds (Figure 2), being three species classified as detritivorous (P. brevis, H. pusarum and O. niloticus); three as insectivorous ( $A$. bimaculatus, $T$. signatus and $M$. dichroura); two like malacophagous (L. piau and T. galeatus); two as carcinophagous (C. monoculus

Table 3. Taxonomic group, number of sampled individuals $(\mathrm{N})$, the percentage of sampled individuals (\%N), number of samples analyzed individuals (NA), the percentage of analyzed individuals (\%NA), of the fish species caught in Umari reservoir, Rio Grande do Norte, Brazil, in the year of 2013.

\begin{tabular}{|c|c|c|c|c|c|}
\hline TAXONOMIC GROUP & $\mathbf{N}$ & $\% \mathrm{~N}$ & NA & \%NA & Catalog \\
\hline \multicolumn{6}{|l|}{ Order Characiformes } \\
\hline \multicolumn{6}{|l|}{ Curimatidae } \\
\hline Curimatella lepidura (Eigenmann \& Eigenmann, 1889) & 2 & 0.27 & 0 & 0.00 & 8969 \\
\hline \multicolumn{6}{|l|}{ Prochilodontidae } \\
\hline Prochilodus brevis Steindachner, 1875 & 25 & 3.38 & 11 & 4.14 & 8974 \\
\hline \multicolumn{6}{|l|}{ Characidae } \\
\hline Astyanax bimaculatus (Linnaeus, 1758) & 169 & 22.84 & 44 & 16.54 & 8965 \\
\hline Moenkhausia dichroura (Kner, 1858) & 164 & 22.16 & 5 & 1.88 & 8958 \\
\hline \multicolumn{6}{|l|}{ Triportheidae } \\
\hline Triportheus signatus (Garman, 1890) & 45 & 6.08 & 34 & 12.78 & 8982 \\
\hline \multicolumn{6}{|l|}{ Anostomidae } \\
\hline Leporinus piau Fowler, 1941 & 24 & 3.24 & 9 & 3.38 & 8967 \\
\hline \multicolumn{6}{|l|}{ Erytrinidae } \\
\hline Hoplias gr. malabaricus (Bloch, 1794) & 31 & 4.19 & 4 & 1.50 & 8946 \\
\hline \multicolumn{6}{|l|}{ Order Perciformes } \\
\hline \multicolumn{6}{|l|}{ Scianidae } \\
\hline Plagioscion squamosissimus (Heckel, 1840) & 51 & 6.89 & 38 & 14.29 & 8966 \\
\hline \multicolumn{6}{|l|}{ Cichlidae } \\
\hline Cichla monoculus Spix \& Agassiz, 1831 & 38 & 5.14 & 7 & 2.63 & 8955 \\
\hline Crencichla menezesi Ploeg, 1991 & 3 & 0.41 & 0 & 0.00 & 8935 \\
\hline Oreochromis niloticus (Linnaeus, 1758) & 8 & 1.08 & 5 & 1.88 & 8986 \\
\hline Astronotus ocellatus (Agassiz, 1831) & 1 & 0.14 & 0 & 0.00 & 8960 \\
\hline \multicolumn{6}{|l|}{ Order Siluriformes } \\
\hline \multicolumn{6}{|l|}{ Loricariidae } \\
\hline Hypostomus pusarum (Starks, 1913) & 10 & 1.35 & 8 & 3.01 & 8934 \\
\hline \multicolumn{6}{|l|}{ Auchenipteridae } \\
\hline Trachelyopterus galeatus (Linnaeus, 1766) & 169 & 22.84 & 101 & 37.97 & 8961 \\
\hline Total & 740 & 100.00 & 266 & 100.00 & \\
\hline
\end{tabular}




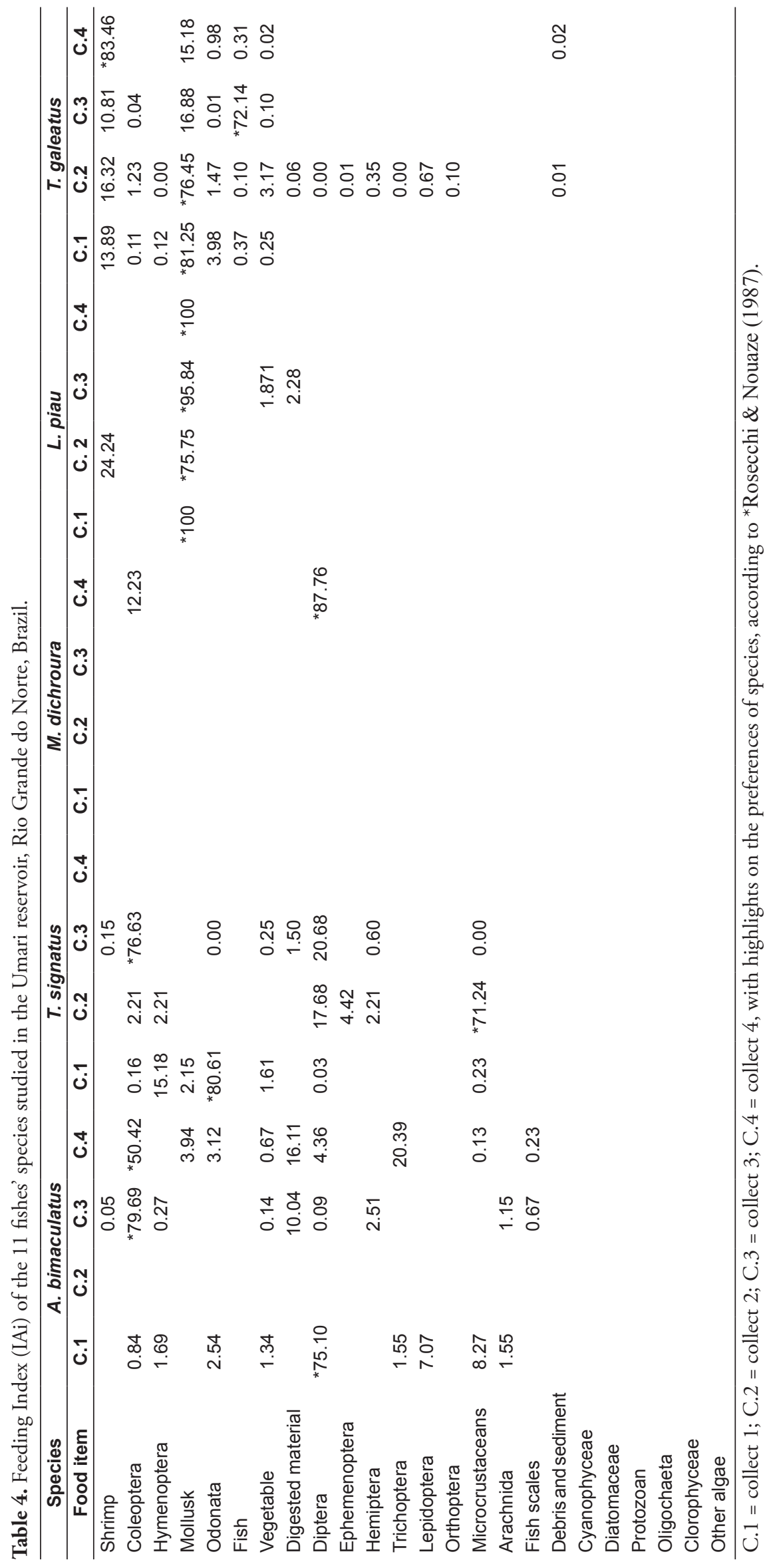




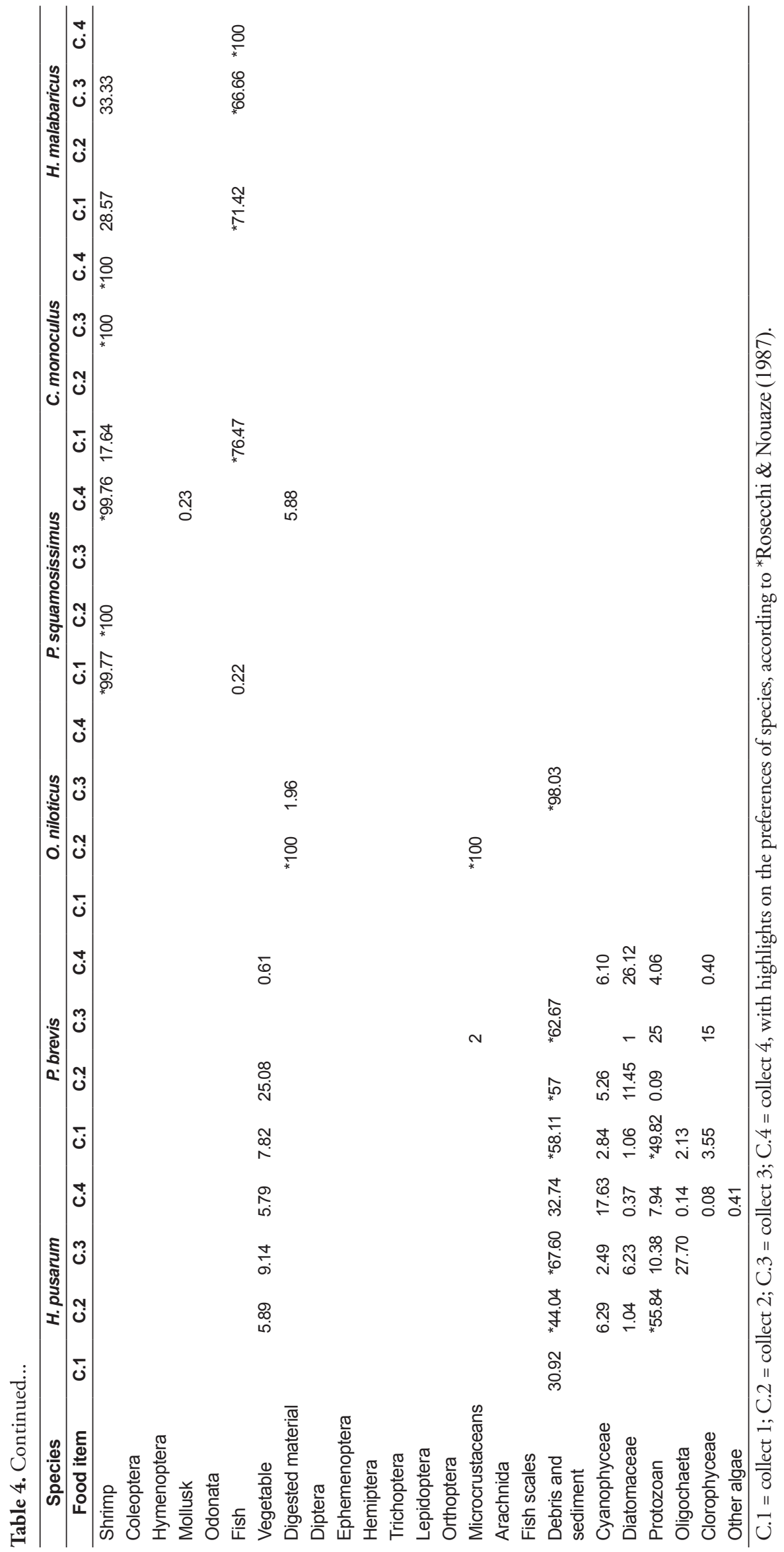




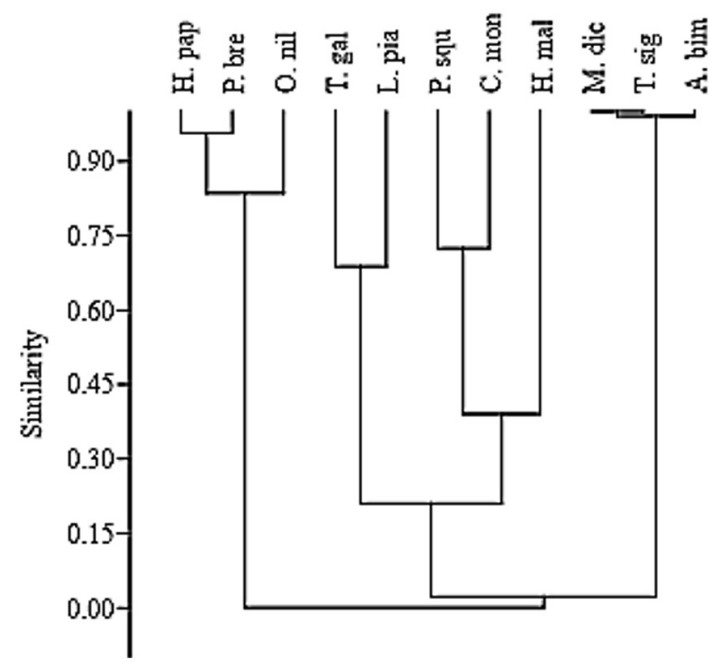

Figure 2. Dendrogram of food similarity from the values of the Feeding Index (IAi) of the 11 fishes' species studied in the Umari reservoir, Rio Grande do Norte, Brazil. Trophic Guilds: Malacophagous (Leporinus piau; Triportheus signatus); Carcinophagous (Cichla monoculus; Plagioscion squamosissimus); Piscivorous (Hoplias gr. malabaricus); Insectivorous (Astyanax bimaculatus; Moenkhausia dichroura; Triportheus signatus); Detritivorous (Hypostomus pusarum; Prochilodus brevis; Oreochromis niloticus).

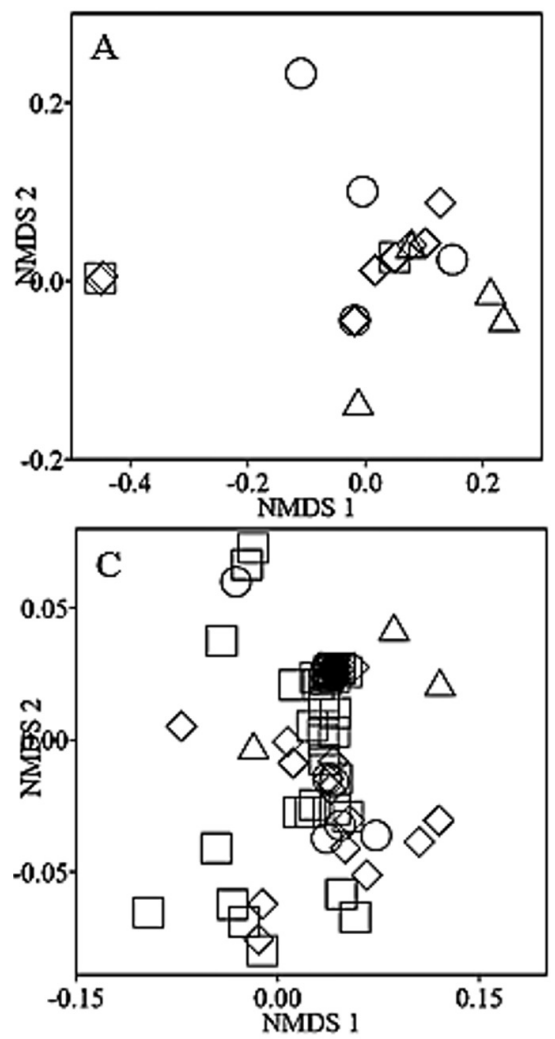

and P. squamosissimus) and only one as piscivorous (H. gr. malabaricus).

The NMDS (Figure 3) evidenced that the insectivorous guild (Figure 3A) had modified the consumption in the insect orders only between May and November $(p=0.04)$. The carcinophagous category (Figure $3 \mathrm{~B}$ ) varied the consumption between February and November $(\mathrm{p}=0.01)$, May and November $(p=0.0003)$. The diet of the malacophagous guild (Figure $3 \mathrm{C}$ ) varied between February and August $(\mathrm{p}=0.006)$, November ( $\mathrm{p}=0.008)$; May and August $(\mathrm{p}=0.01)$, November $(\mathrm{p}=0.007)$ and; August and November $(\mathrm{p}=0.007)$. Already detritivorous diet did not vary between the studied months $(\mathrm{p}=0.33)$ (Figure $3 \mathrm{D})$, according to Permutational Multivariate Analysis of Variance (PERMANOVA).

\section{Discussion}

The trophic categories identified had demonstrated a diet composed of different items throughout the study period. For the insectivorous guild were recorded insects, shrimp, other invertebrates, fish, digested material, detritus,
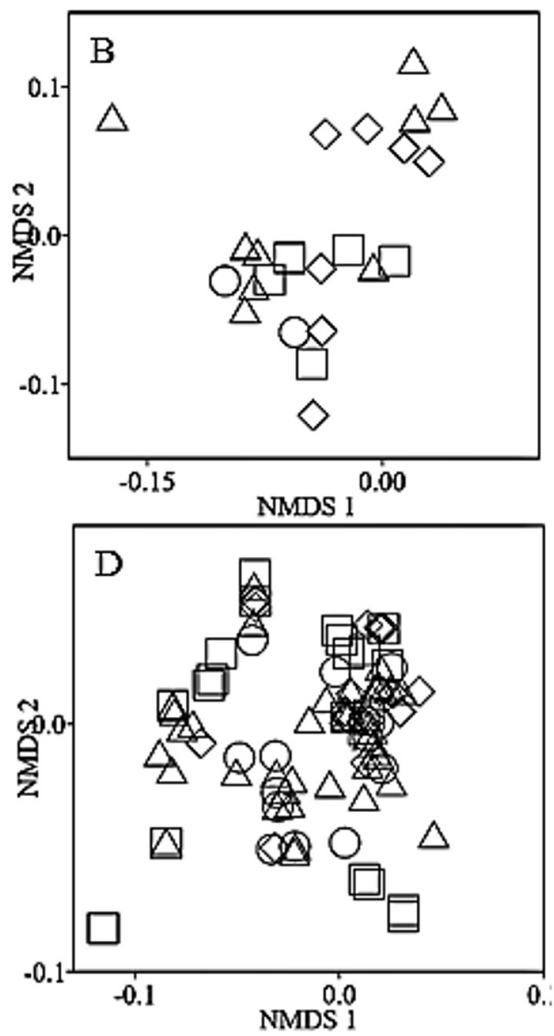

Figure 3. Graphical representation of the NMDS, showing the variation in the consumption of trophic guilds food resources present in the Umari reservoir, Rio Grande do Norte, Brazil. Guilds: Insectivorous (A); Carcinophagous (B); Malacophagous (C); Detritivorous (D), February o; May $\triangle$; August $\square$; November $\diamond$. 
sediment, vegetables, mollusk, and zooplankton. The malacophagous present mollusks, insects, shrimp, digested the material, vegetables, and fish. Detritivorous had consumed detritus, sediment, zooplankton and phytoplankton. In turn, the carcinophagous category preyed shrimp, fish, and mollusks. As for the piscivorous guild had predominated the fish item, was also registered shrimp.

The modification in the food items consumption through the year, influenced by the oscillations in the water volume of the reservoir, can be associated with the rainy period, in which it increases the water level of the reservoir, flooding the marginal vegetation, previously dry, increasing the area of prey occupation (insects, mollusks and shrimps) making it difficult the predation of these items. In this period also occur an addition of items of allochthonous origin, such as plant material and a high number of terrestrial arthropods, which fall on the surface of the body of water, depending on the degree of marginal vegetation cover (Silva et al., 2012a). The opposite occurs during the dry season, when the water level back off, exposing previously the submerged areas, decreasing the habitat diversity, letting the prey more vulnerable, making easier its capture.

Although the ichthyofauna of the reservoirs are mainly maintained by food of autochthonous origin, the allochthonous resources, are also representative parts in the energy input to the aquatic ecosystem, because provide different sources of food (vegetal/animal) for the maintenance and functioning of the fish communities (Moraes et al., 2013). The changes in the diet of the insectivorous guild between May and November may be due to water volume variations in the reservoir, once that in May the largest water volume was recorded in the reservoir, and in November, where was recorded one of the smaller water volumes. The diversity of insects can vary seasonally, becoming more or less available according to the seasons of the year. Characteristic that probably influenced the consumption of different orders of insects by the insectivorous.

The flooding period of the reservoirs generally, coinciding with the insect's reproduction period, increasing mainly the availability of the aquatic shapes of these individuals. Aquatic insects present a wide distribution in the body of water, being able to be found in different microhabitats, such as sediment, macrophytes, rocks, foliage, and submerged trunks allowing them to be exploited by fish of different feeding tactics, (Gordon et al.,
2004; Vidotto-Magnoni \& Carvalho, 2009). Besides, the elevation of water body volume increases the abundance and availability of terrestrial invertebrates such as insects in the environment (Bonato et al., 2012).

The reduction flooded area provoke a decrease terrestrial insect, as well as the microhabitats, leaving the aquatic insects most vulnerable to predation, and the fish species, to minimize a competition for resources or a niche overlap, come to consume other food sources (Kotler \& Brown, 2007), obeying to the specific morphological adaptations of each species and/or their use of the microhabitat (Mazzoni et al., 2010). This factor may also be attributed to the change of the insectivorous guild diet, once its members besides insects also had consumed shrimp, fish, vegetables, and mollusk.

The high consumption rates on the introduced shrimp Macrobrachium amazonicum, by the species $P$. squamosissimus and C. monoculus, allowed the framework in guild carcinophagous. $M$. amazonicum represents the main freshwater shrimp, presenting a fast development and wide adaptive plasticity to the several environments (Vergamini et al., 2011). In terms of the seasonal changes observed in the diet of the carcinophagous guild, these may be the result of the water level increase in the reservoir providing new shelters for the shrimps, hampering their capture (Freire et al., 2012), besides the carried sediment influencing the water transparency, slowing the phytoplankton growth, making food more restricted to the individuals, factors which may also decrease the shrimp availability. However, the reduction of the water volume promotes the decrease in the colonization area, sediment precipitation occurs, increasing the water transparency and the insolation allowing the proliferation of microalgae, food for the shrimp, and consequently, a greater availability of these individuals may occur.

Studies have been described C. monoculus in a reservoir environment as piscivorous species expert (Gomiero \& Braga, 2004; Novaes et al., 2004; Capra \& Bennemann, 2009). Concerning P. squamosissimus, the species has been documented with great trophic and opportunistic plasticity (Santos et al., 2014; Ferreira Filho et al., 2014). Therefore, the description of these species as carcinophagous, is possibly related to the abundance and availability of the shrimp $M$. amazonicum in the Umari reservoir, facilitating their predation, following the theory of optimal foraging proposed by MacArthur \& Pianka (1966), the organisms 
are adapted to obtain food with the highest energy value by spending the minimum of energy as possible, once that the members of the guild also consumed fish and mollusks. Souza et al. (2017) state that the greater consumption of shrimp by P. squamosissimus in the Santa Cruz reservoir is likely by aspects of life history of species in the selection of their food. Regarding the selection of prey type and size, including limitations imposed by predatory morphology, such as mouth size and behavioral strategies, such as those involved in prey hunting and killing.

In relation to the malacophagous guild, which presented major alterations in the consumption of items throughout the study time, may be connected to the availability of shelter, influenced by the oscillations of the water volume, once the elevation of the water level increases the area of colonization of mollusks, and the reduction decreases this area, leaving the mollusks more susceptible to predation. Mollusks are food resources of great importance in Neotropical fish diet, which can be result such for Gastropoda as for Bivalve orders (Winemiller et al., 2008). These two orders recorded in the diet of L. piau and T. galeatus in the present work. Besides the mollusks, the records of the items insect, shrimp and vegetable in the diet of $L$. piau, as well as fish, insects, vegetables and shrimp in T. galeatus diet, show that both species are generalist and opportunistic, with a flexible diet whose eating habits and the type of consumed food depend on the availability in the environment, factors that may be associated with the changes in their diet in the Umari reservoir.

The predominant consumption of fish mainly small, such as $A$. bimaculatus, by the species $H$. gr. malabaricus, the only species classified as piscivore, clearly shows that trahira is a top predator for the ichthyofauna of the studied ecosystem. The piscivorous feeding habit of this species in environments of Neotropical regions is well documented in the literature (Corrêa \& Piedras, 2008). Experimental studies in the mesocosm have demonstrated that the trahira has an important role in the trophic structuring and regulation of forage species in aquatic environments (Mazzeo et al., 2010). Therefore, this species deserves special attention in studies that seek the conservation of the ichthyofauna in dammed environments, mainly those related to the detritivorous guild, the predominance in the detritus item consumption may be derived of the flooding of a large amount of terrestrial phytomass, which promotes a high production of detritus in reservoirs, as well as depletions in the water level, can favor the growth of grasses and other plants in marginal regions, which with its subsequent submergence, also contribute to detritus production (Agostinho et al., 2007). However, the lack of evidence of changes in the consumption of items by the detritivorous guild, was given by the abundance of this resource, the morphology of the buccal apparatus and digestive tract of the species, favorable to explore benthic environments, consuming then detritus, microalgae, and micro faun associated with the sediment, demonstrating the importance of this food resource for this guild, and for other ecosystem communities, once that detritivorous fish constitute in important links in the energy flow and nutrient cycling processes (Bowen, 1984; Resende, 2008). Oliveira et al. (2016a) in the Santa Cruz reservoir and Oliveira et al. (2016b) in the Pau dos Ferros reservoir, where it was observed that the dry conditions provided the accumulation of resources in the reservoirs, such as organic matter and debris, favoring the establishment of detritivorous of the family Loricariidae, besides the Curimatidae and Prochilodontidae of the order Characiformes.

In general, the changes in the water volume of Umari dam, were determinant in the items variety, as well as in the seasonal changes in the diet of the studied species, demonstrating a trophic plasticity, common in most freshwater fish, due to the several feeding tactics associated with the items capture, which contributes to greater success in predation and exploitation of available food resources in the environment. The strategy of using the most available resources is essential because allows the species to persist in the environments, once it allows them to broaden their resource range (Delariva et al., 2013) allowing tolerate the most severe impacts.

\section{Final Considerations}

The different fish species of the Umari reservoir, distributed in five trophic guilds, had consumed different food sources, demonstrating a food flexibility, using the resources that are more abundant and available in the environment, this strategy is extremely important for the survival, in Neotropical aquatic environments and, the influence of the water volume of the reservoir in the diet of most guilds, demonstrates that the variations in the water volume in the reservoir, do not influence in the same way, the diet of the local ichthyofauna. 


\section{References}

AGOSTINHO, A.A., GOMES, L.C. and PELICICE, F.M. Os reservatórios brasileiros. In: A.A. AGOSTINHO, L.C. GOMES and F.M. PELICICE, eds. Ecologia e manejo de recursos pesqueiros em reservatórios do Brasil. Maringá: EDUEM, 2007, pp. 39-97.

AGOSTINHO, A.A., PELICICE, F.M. and GOMES, L.C. Dams and the fish fauna of the Neotropical region: impacts and management related to diversity and fisheries. Brazilian Journal of Biology = Revista Brasileira de Biologia, 2008, 68(4, Suppl), 1119-1132. http://dx.doi.org/10.1590/S151969842008000500019. PMid:19197482.

BONATO, K.O., DELARIVA, R.L. and SILVA, J. Diet and trophic guilds of fish assemblages in two streams with different anthropic impacts in the northwest of Paraná, Brazil. Zoologia, 2012, 29(1), 27-38. http:// dx.doi.org/10.1590/S1984-46702012000100004.

BOWEN, S.H. Detritivory in Neotropical fish communities. In: T.M. ZARET. Evolutionary ecology of Neotropical freshwater fishes: proceedings of the 1st international symposium on systematics and evolutionary ecology of Neotropical freshwater fishes. Dekaeb: Dr W. Junk Publishers, 1984, pp. 59-66. http://dx.doi.org/10.1007/978-94-015-7682-6_4.

CAPRA, L.G. and BENNEMANN, S.T. Low feeding overlap between Plagioscion squamosissimus (Heckel, 1840) and Cichla monoculus (Spix \& Agassiz, 1831), fishes introduced in tropical reservoir of South Brazil. Acta Limnologica Brasiliensia, 2009, 21(3), 343-348.

CORRÊA, F. and PIEDRAS, S.R.N. Alimentação de Cyphocharax voga (Hensel, 1869) (Characiformes, Curimatidae) no arroio Corrientes, Pelotas, Rio Grande do Sul, Brasil. Biotemas, 2008, 21(4), 117-122. http://dx.doi.org/10.5007/21757925.2008v21n4p117.

CRUZ, C.D. and CARNEIRO, P.C.S. Modelos biométricos aplicados ao melhoramento genético. Viçosa: Editora UFV, 2003.

DELARIVA, R.L., HAHN, N.S. and KASHIWAQUI, E.A.L. Diet and trophic structure of the fish fauna in a subtropical ecosystem: impoundment effects. Neotropical Ichthyology, 2013, 4(11), 891-904. http:// dx.doi.org/10.1590/S1679-62252013000400017.

EMPRESA DE PESQUISA AGROPECUÁRIA DO RIO GRANDE DO NORTE-EMPARN. Monitoramento pluviométrico [online]. Parnamirim, 2016 [viewed 5 Oct. 2016]. Available from: http://189.124.201.150/ monitoramento/monitoramento.php

FERREIRA FILHO, V.P., GUERRA, T.P., LIMA, M.C.S., TEIXEIRA, D.F.F., COSTA, R.R., ARAÚJO, I.M.S., EL-DEIR, A.C. and MOURA, G.J.B. Padróes ecomorfológicos associados à dieta de Plagioscion squamosissimus (Perciformes, Scianidae) em reservatório permanente, no
Nordeste do Brasil. Iheringia. Série Zoologia, 2014, 104(2), 134-142. http://dx.doi.org/10.1590/1678476620141042134142.

FREIRE, J.L., MARQUES, C.B. and SILVA, B.B. Estrutura populacional e biologia reprodutiva do camarão-da-amazônia Macrobrachium amazonicum (Heller, 1862) (Decapoda: Palaemonidae) em um estuário da região nordeste do Pará, Brasil. Brazilian Journal of Science and Technology, 2012, 16(2), 6576. http://dx.doi.org/10.14210/bjast.v16n2.p65-76.

GANDINI, C.V., SAMPAIO, F.A.C. and POMPEU, P.S. Hydropeaking effects of on the diet of a Neotropical fish community. Neotropical Ichthyology, 2014, 12(4), 795-802. http://dx.doi.org/10.1590/1982-022420130151

GOMIERO, L.M. and BRAGA, F.M.S. Feeding of introduced species of Cichla (Perciformes, Cichlidae) in Volta-Grande reservoir, river Grande (MG/SP). Brazilian Journal of Biology = Revista Brasileira de Biologia, 2004, 64(4), 787-795. http:// dx.doi.org/10.1590/S1519-69842004000500008. PMid:15744419.

GORDON, N.D., MCMAHON, T.A., FINLAYSON, B.L., GIPPEL, C.J. and NATHAN, R.J. Stream hydrology: an introduction for ecologists. 2nd ed Chichester: John Willey \& Sons, 2004, 429 p.

GOULDING, M. The fishes and the forest: explorations in Amazonian natural history. Berkeley: University of California Press, 1980.

HAMMER, O., HARPER, D.A.T. and RYAN, P.D. PaST: Palaeontological Statistics, version 1.32 [software]. 2004 [viewed 2 Jan. 2004]. Available from: http://folk.uio.no/ohammer/past/

HELLAWELL, J.M. and ABEL, R. A rapid volumetric method for the analysis of the food of fishes. Journal of Fish Biology, 1971, 3(1), 29-37. http://dx.doi. org/10.1111/j.1095-8649.1971.tb05903.x.

HYNES, H.B.N. The food of freshwater sticklebacks (Gasterosteus aculeatus and Pygosteus pungitius) with a review of methods used in studies of the food of fishes. Journal of Animal Ecology, 1950, 19(1), 36-58. http://dx.doi.org/10.2307/1570.

HYSLOP, E.J. Stomach contents analysis: a review of methods and their application. Journal of Fish Biology, 1980, 17(4), 411-429. http://dx.doi. org/10.1111/j.1095-8649.1980.tb02775.x.

KAWAKAMI, E. and VAZZOLER, G. Método gráfico e estimativa de índice alimentar aplicado no estudo de alimentaçáo de peixes. Boletim do Instituto Oceanográfico, 1980, 29(2), 205-207. http://dx.doi. org/10.1590/S0373-55241980000200043.

KOTLER, B.P. and BROWN, J.S. Community ecology. In: D.A. STEPHENS, J.S. BROWN and R.C. YDENBERG, eds. Foraging: behavior and ecology. Chicago: University of Chicago Press, 2007, pp. 397-434. 
MACARTHUR, R.H. and PIANKA, E.R. On optimal use of a patchy environment. American Naturalist, 1966, 100(916), 603-609. http://dx.doi. org/10.1086/282454.

MAZZEO, N., IGLESIAS, C., TEIXEIRA-DE MELLO, F., BORTHAGARAY, A., FOSALBA, C., BALLABIO, R., LARREA, D., VILCHES, J., GARCÍA, S., PACHECO, J.P. and JEPPESEN, E. Trophic cascade effects of Hoplias malabaricus (Characiformes, Erythrinidae) in subtropical lakes food webs: a mesocosm approach. Hydrobiologia, 2010, 644(1), 325-335. http://dx.doi.org/10.1007/ s10750-010-0197-8.

MAZZONI, R., MORAES, M., REZENDE, C.F. and MIRANDA, J.C. Alimentação e padrôes ecomorfológicos das espécies de peixes de riacho do alto rio Tocantins, Goiás, Brasil. Iheringia. Série Zoologia, 2010, 100(2), 162-168. http://dx.doi. org/10.1590/S0073-47212010000200012.

MCCAFFERTY, W.P. Aquatic entomology: the fishermen's and ecologist's illustrated guide to insects and their relatives. Boston: Jones and Bartlett Publishers, 1981.

MEIRELES, A.C.M., FRISCHKORN, H. and ANDRADE, E.M. Sazonalidade da qualidade das águas do açude Edson Queiroz, Bacia do Acaraú, no Semiárido cearense. Revista Ciência Agronômica, 2007, 38(1), 25-31.

MÉRONA, B. and VIGOUROUX, R. The role of ecological strategies in the colonization success of pelagic fish in a large tropical reservoir (Petit-Saut Reservoir, French Guiana). Aquatic Living Resources, 2012, 25(1), 41-54. http://dx.doi.org/10.1051/ alr/2011153.

MERRITT, R.W. and CUMMINS, K.W. An introduction to the aquatic insects of North America. 3rd ed. Dubuque: Kendall/Hunt, 1996, 722 p.

MORAES, M., REZENDE, C.F. and MAZZONI, R. Feeding ecology of stream-dwelling Characidae (Osteichthyes: Characiformes) from the upper Tocantins River, Brazil. Zoologia, 2013, 30(6), 645-651. http://dx.doi.org/10.1590/S198446702013005000003 .

NEEDHAM, J.G. and NEEDHAM, P.R. Guia para el estudio de los seres vivos de las aguas dulces. Barcelona: Reverté S.A., 1982.

NOVAES, J.L.C., CARAMASCHI, E.R. and WINEMILLER, K.O. Feeding of Cichla monoculus Spix, 1829 (Teleostei: Cichlidae) during and after reservoir formation in the Tocantins River, Central Brazil. Acta Limnologica Brasiliensia, 2004, 16(1), 41-49.

OLIVEIRA, J.F., COSTA, R.S., NOVAES, J.L.C., REBOUÇAS, L.G.F., MORAIS-SEGUNDO, A.L.N. and PERETTI, D. Efeito da seca e da variação espacial na abundância de indivíduos nas guildas tróficas da ictiofauna em um reservatório no
Semiárido Brasileiro. Boletim do Instituto de Pesca, 2016a, 42(1), 51-64. http://dx.doi.org/10.20950/1 678.2305.2016v42n1p51.

OLIVEIRA, J.F., MORAES-SEGUNDO, A.L.N., NOVAES, J.L., COSTA, R.S., FRANÇA, J.S. and PERETTI, D. Trophic structure of the ichthyofauna in a Brazilian semiarid reservoir. Iheringia. Série Zoologia, 2016b, 106, 1-9.

PERETTI, D. and ANDRIAN, I.F. Trophic estructure of fish assembleges in five permanent lagoons of the high Paraná River floodpain, Brasil. Environmental Biology of Fishes, 2004, 71(1), 95-103. http://dx.doi. org/10.1023/B:EBFI.0000043155.76741.a1.

RESENDE, E.K. Pulso de inundação: processo ecológico essencial à vida no Pantanal. Corumbá: Embrapa Pantanal, 2008, 16 p. Documentos, vol. 94.

RIBEIRO, A.R., BIAGIONI, R.C. and SMITH, W.S. Estudo da dieta natural da ictiofauna de um reservatório centenário, São Paulo, Brasil. Iheringia. Série Zoologia, 2014, 104(4), 404-412. http://dx.doi. org/10.1590/1678-476620141044404412.

ROSECCHI, E. and NOUAZE, Y. Comparaison de cinq índices alimentaires utilisés dans I'analyse des contenus stomacaus. Revue des Travaux de l'Institut des Pêches Maritimes, 1987, 49(3-4), 111-123.

SANTOS, N.C.L., MEDEIROS, T.N., ALROCHA, A.A.F., DIAS, R.M. and SEVERI, W. Uso de recursos alimentares por Plagioscion squamosissimus - piscívoro não-nativo no reservatório de sobradinho-BA, Brasil. Boletim Instituto de Pesca, 2014, 40(3), 397-408.

SECRETÁRIA DE RECURSOS HÍDRICOS E MEIO AMBIENTE DO ESTADO DO RIO GRANDE DO NORTE - SEMARH. Natal, 2013 [viewed 20 May 2013]. Available from: http://www.semarh. rn.gov.br/

SECRETARIA DO MEIO AMBIENTE E DOS RECURSOS HÍDRICOS - SEMARH [viewed 5 Oct. 2016]. Monitoramento. Natal, 2016 Available from: http://www.semarh.rn.gov.br/Conteudo.asp? TRAN $=$ ITEM $\&$ TARG $=17381 \& A C T=\& P A G E=0$ $\& \mathrm{PARM}=\& \mathrm{LBL}=$ Servi $\% \mathrm{E} 7 \mathrm{os}$

SILVA, D.A., PESSOA, E.K.R., COSTA, S.A.G.L., CHELLAPPA, N.T. and CHELLAPPA, S. Ecologia alimentar de Astyanax lacustris (Osteichthyes: Characidae) na Lagoa do Piató, Assú, Rio Grande do Norte, Brasil. Biota Amazônia, 2012b, 2(1), 74-82. http://dx.doi.org/10.18561/2179-5746/ biotaamazonia.v2n1p74-82.

SILVA, J.C., DELARIVA, R.L. and BONATO, K.O. Food-resource partitioning among fish species from a first-order stream in northwestern Paraná, Brazil. Neotropical Ichthyology, 2012a, 10(2), 389-399. http://dx.doi.org/10.1590/S167962252012005000008 .

SOUZA, A.E.F., OLIVEIRA, J.F., PERETTI, D., FERNANDES, R., COSTA, R.S. and NOVAES, 
J.L.C. Effects of a supraseasonal drought on the ecological attributes of Plagioscion squamosissimus (Heckel, 1840) (Pisces, Sciaenidae) in a Brazilian Reservoir. The Scientific World Journal, 2017, 2017, 1-9. http://dx.doi.org/10.1155/2017/5930516. PMid:28326431.

VERGAMINI, F.G., PILEGGI, L.G. and MANTELATTO, F.L. Genetic variability of the Amazon River prawn Macrobrachium amazonicum (Decapoda, Caridea, Palaemonidae). Contributions to Zoology, 2011, 80(1), 67-83.

VIDOTTO-MAGNONI, A.P. and CARVALHO, E.D. Aquatic insects as the main food resource of fish the community in a Neotropical reservoir. Neotropical
Ichthyology, 2009, 7(4), 701-708. http://dx.doi. org/10.1590/S1679-62252009000400020.

WINEMILLER, K.O., AGOSTINHO, A.A. and CARAMASCHI, E.P. Fish ecology in tropical streams. In: D. DUDGEON, ed. Tropical stream ecology. 1st ed. London: Elsevier, 2008, 334 p. http:// dx.doi.org/10.1016/B978-012088449-0.50007-8.

ZAVALA-CAMIN, L.A. Introdução aos estudos sobre alimentação natural em peixes. Maringá: Editora da Universidade Estadual de Maringá, 1996, 129 p.

Received: 22 November 2016 Accepted: 14 August 2017 